\title{
PENGEMBANGAN BAHAN AJAR BALOK DAN KUBUS BERBASIS ETNOMATEMATIKA DENGAN KONTEKS CANDI JOLOTUNDO TRAWAS MOJOKERTO
}

\author{
Iid Fitria Ningrum \\ Institut Agama Islam Negeri Jember \\ e-mail: $\underline{\text { iidfitrian25@gmail.com }}$ \\ Fikri Apriyono \\ Institut Agama Islam Negeri Jember \\ e-mail: fikrimath@gmail.com
}

\begin{abstract}
Abstrak
Etnomatematika adalah suatu aktivitas kehidupan dari elemen-elemen masyarakat yang menjai rutinitas, atau ciri khas dari suatu daerah yang memiliki konsep-konsep matematika. Tujuan penelitian ini adalah: 1) Menjelaskan proses pengembangan bahan ajar balok dan kubus berbasis etnomatematika dengan konteks candi Jolotundo Trawas Mojokerto. 2) Menjelaskan kelayakan bahan ajar balok dan kubus berbasis etnomatematika dengan konteks candi Jolotundo Trawas Mojokerto yang dilihat dari aspek kelayakan, kevalidan dan keefektifan suatu produk. Penelitan ini memperoleh kesimpulan 1) Proses pengembangan bahan ajar balok dan kubus dibagi menjadi beberapa thap diantaranya yaitu; Tahap pertama yang dilakukan ialah tahap Analysis (analisis). Dalam tahap ini terdapat 3 langkah, yaitu (1) Analisis kebutuhan; (2) Analisis karakteristik siswa; dan (3) Analisis Etnomatematika. Tahap kedua yang dilakukan ialah tahap Design (perancangan). Tahap ini merupakan tahap penyusunan desain LKS, serta penyusunan desain instrumen. Tahap ketiga ialah Development (pengembangan). Dalam tahap ini dilakukan penilaian oleh para ahli. Dari hasil penilaian tersebut diperoleh penilaian kevalidan dari LKS. Selanjutnya, tahap keempat ialah Implementation (penerapan). Pada tahap ini dilakukan uji coba kepada siswa SMP Penanggungan Ngoro Mojokerto kelas VIII-A dengan diterapkannya pembelajaran menggunakan LKS yang telah dikembangkan. Sedangkan tahap kelima ialah Evaluation (evaluasi). Pada tahap ini diperoleh hasil penilaian yang digunakan untuk mengetahui kepraktisan dan keefektifan perangkat pembelajaran. 2) Menurut Van den Nieveen dalam Rachmad (2010) menyatakan, bahwa dalam penelitian pengembangan model pembelajaran perlu beberapa kriteria kualias atau kelayakan diantaranya; a) Kevalidan. Kriteria valid terpenuhi karena penilaian dari ketiga validator menghasilkan rata-rata total dalam kategori baik, dengan nilai rata-rata mencapai 3,2; b) Kepraktisan. Kriteria praktis terpenuhi karena LKS yang dikembangkan mendapatkan nilai rata-rata 3,9 dengan kriteria sangat baik dari angket respon siswa maupun guru yang sudah disebar; c) Keefektifan. Berdasarkan nilai post-test yang diberikan pada tahap uji coba, diperoleh data bahwa sebanyak $69 \%$ siswa dinyatakan tuntas. Dari ketiga aspek tersebut dapat diketahui bahwa bahan ajar yang dikembangkan layak untuk dipergunakan.
\end{abstract}

Kata Kunci: Bahan Ajar, Etnomatematika, Candi Jolotundo

\begin{abstract}
Etnomathematics is a living activity of elements of society that becoming routine, or typical of an area with mathematical. The purpose of this study are: 1) to explain the development of ethnose-based block materials and cubes with the context of Jolotundo Trawas Mojokerto. 2) to explain the worth of ethnose-based blocks materials and cube with the context of Jolotundo Trawas Mojokerto temple that is viewed from the feasibility, validity, and effectiveness of a product. The study came to some conclusions 1) the process of developing blocks and cubes that was divided into several steps; the first phase is analysis. This stage has three steps, which are (1) the needs analysis; (2) student characteristics analysis; and (3) ethnomath analysis. The second step is designing. It was the drafting design of the LKS, and the instrument. The third stage is development. At this stage, it came from professional appraisal. From those assessments, it was found a valiance assessment from the LKS. Next, the fourth stage is aplication. At this stage, a trial was carried out on the junior high school application of Ngoro MojokertoVIII-A class with the application of learning using the LKS that had been developed. The fifth stage is an evaluation. At this stage, it was found the assessment results used to know the practicality and effectiveness of the learning tools. 2) according to Van den Nieveen in Rachmad (2010), the model development study requires some of the characteristics quality or practical criteria such as: a) validity.
\end{abstract}


Valid criteria was met because the judgments of the three validators yield a total average in good categories with an average of 3,$2 ;$ b) practicality. Practical criteria is met becausethe LKS developed an average 3,9 with excellent criteria from both student and teacher response numbers; c) effectiveness. Based on the value of a post-test given at the testing stage, the data obtained that a total of $69 \%$ of students are completed. From these three aspects, it is known that the developed teaching material is worthy to be development.

Keywords: material, ethnomathematic, temple of Jolotundo

\section{PENDAHULUAN}

Pembelajaran matematika bagi para siswa merupakan pembentukan pola pikir dalam pemahaman suatu pengertian maupun dalam penalaran suatu hubungan diantara pengertianpengertian itu. Dalam pembelajaran matematika, para siswa dibiasakan untuk memperoleh pemahaman melalui pengalaman tentang sifat-sifat yang dimiliki dan yang tidak dimiliki dari sekumpulan objek (abstraksi). Siswa diberi pengalaman menggunakan matematika sebagai alat untuk memahami atau menyampaikan informasi misalnya melalui persamaan-persamaan, atau tabel-tabel dalam model-model matematika yang merupakan penyederhanaan dari soalsoal cerita atau soal-soal uraian matematika lainnya. Akan Tetapi dari pengalaman tersebut banyak siswa-siswa yang kesulitan mengenai penyederhanan soal-soal cerita yang berkaitan dengan kehidupan sehari-hari. Seperti halnya pada salah satu sekolah yang peneliti akan jadikan sampel. Disana banyak siswa-siswi yang kesulitan mengaplikasikan materi matematika secara konkrit pada dunia nyata.

Dengan demikian pendidikan dan kebudayaan (kebiasaan) memiliki hubungan yang sangat erat. Budaya sekitar siswa mampu membantu siswa untuk menyederhanakan soal-soal cerita yang berkaitan dalam kehidupan sehari-hari secara konkrit. Sehingga tidak menutup kemungkinan bahwa kebudayaan dijadikan rujukan sebagai bahan ajar dalam proses pembelajaran. Oleh karena itu pengembangan bahan ajar berbasis budaya perlu dilakukan. Hal ini ditujukan agar pembelajaran menjadi kondusif, karena untuk terwujudnya proses pembelajaran yang kondusif perlu didukung oleh beberapa faktor, misalnya dalam memilih bahan ajar, sarana, dan fasilitas pendukung lainnya. Dalam pemilihan bahan ajar, ada beberapa prinsip yang perlu diperhatikan, yaitu prinsip relevansi, konsistensi, dan kecukupan. Prinsip relevansi artinya materi pembelajaran harus relevan atau berkaitan dengan pencapaian standart kompetensi dan kompetensi dasar. Prinsip konsistensi artinya keajegan, yaitu jika ada empat kompetensi dasar, maka bahan ajar yang harus diajarkan juga harus meliputi empat macam. Prinsip kecukupan artinya materi yang diajarkan hendaknya cukup memadai dalam membantu siswa menguasai kompetensi dasar yang diajarkan.

Materi bangun ruang sisi datar, khususnya pada balok dan kubus banyak menjadi poblem bagi paa siswa-siswi. Pada materi tersebut siswa-siswi merasa kebingungan jika tidak 
diaplikasikan kepada benda yang konkrit. Karena balok dan kubus merupakan bangun 3D yang tidak semua siswa-siswi mampu mengetahui bangun tersebut dengan baik, jika tidak diperkenalkan pada benda-benda disekitar mereka. Seperti halnya, kardus bekas mie instan, batu bata, kulkas, tv, pintu, dan lain sebagainya. Akan tetapi siswa-siswi tidak dihadapkan dengan itu saja, melainkan siswa-siswi juga dituntut untuk memahami luas permukaan bangun dan volume bangun yang diminta.

Salah satu benda yang memliki konsep kubus dan balok disekiar lingkungan siswa yang dapat diaplikasikan adalah bangunan candi Jolotundo Trawas Mojokerto. Karena candi tersebut terletak tidak jauh dari sekolah yang peneliti jadikan tempat penelitian.

Dalam penelitian dan pengembangan ini peneliti membatasi bahan ajar yang akan dikembangkan yaitu Lembar Kerja Siswa (LKS). Dengan adanya LKS berbasis etno atau budaya, siswa tidak hanya belajar mengenai ilmu menghitung saja akan tetapi siswa juga belajar tentang budaya. Selain dapat melestarikan budaya disekitar siswa, siswa juga dapat memahami materi yang disajikan dengan baik. Inovasi tersebut sangat diperlukan untuk proses belajar siswa. Karena dengan adanya LKS yang menarik siswa akan merasa tertarik untuk belajar dengan suasana baru. Sehingga siswa dengan mudah menerima materi yang diberikan. Akan tetapi dalam penelitian sebelumnya, tidak banyak peneliti yang melakukan penelitian dan pengembangan LKS yang berbasis budaya sekitar. Padahal penelitian dan pengembangan yang memanfaatkan budaya lokal untuk pemahaman siswa pada mata pelajaran matematika memiliki dampak yang cukup baik. Seperti halnya pada penelitian yang dilakukan oleh Thentria Yohana Sianturi "Pengembangan Buku Ajar Matematika Siswa Berbasis Budaya Jambi untuk Meningkatkan Kreativitas Berpikir Siswa SMP" yang menyatakan buku ajar yang dikembangkan dapat membantu proses belajar mengajar dengan baik.

Berdasarkan uraian diatas, peneliti tertarik melakukan "Pengembangan Bahan Ajar Balok dan Kubus Berbasis Etnomatemaika dengan konteks Candi Jolotundo Trawas Mojokerto" Sebelum melakukan penelitian ini, peneliti sudah melakukan observasi awal sebagai bekal dan persiapan untuk melakukan penelitian, serta kebenaran tentang adaya candi peninggalan kerajaan Majapahit di desa Seloliman Trawas Mojokerto. Dari observasi awal, peneliti telah memperoleh informasi hal-hal yang dibutuhkan ketika penelitian, serta peneliti juga telah menetapkan calon subyek penelitian yaitu juru rawat pada petirtaan candi Jolotundo Trawas Mojokerto. Serta peneliti juga mendapatkan calon subyek peneliti, yaitu siswa-siswi SMP Penanggungan Ngoro Mojokerto. 
Berdasarkan latar belakang masalah diatas, maka tujuan pengembangan ini adalah sebagai berikut:

1. Menjelaskan proses pengembangan bahan ajar balok dan kubus berbasisis etnomatematika dengan konteks candi Jolotundo Trawas Mojokerto.

2. Menjelaskan kelayakan bahan ajar balok dan kubus berbasis etnomatematika dengan konteks candi Jolotundo Trawas Mojokerto yang dilihat dari aspek kevalidan, kepraktisan dan keefektifan suatu produk.

\section{METODE PENELITIAN}

A. Prosedur Penelitian dan Pengembangan

Tahap-tahap penelitian pengembangan bahan ajar yang dilakukan sebagi berikut.

\section{Analysis (Analisis)}

Analisis yang dilakukan pada tahap ini adalah sebagai berikut:

a. Analisis Kebutuhan

Analisis kebutuhan yang dilakukan yaitu mengumpulkan informasi tentang bahan ajar apa yang perlu untuk dikembangkan, serta kurikulum, KI (Kompetensi Inti) dan KD (Kompetensi Dasar) yang dipakai di sekolah. Pengumpulan informasi ini dilakukan dengan wawancara terhadap guru matematika SMP Penanggungan Ngoro Mojokerto.

b. Analisis Karakteristik Siswa

Analisis karakteristik siswa dilakukan untuk mengetahui cara berpikir siswa SMP Penanggungan kelas VIII pada umumnya. Analisis ini akan dilaksanakan dengan cara mewawancarai guru mata pelajaran matematika, kajian teori dan pengamatan secara langsung ketika proses pembelajaran berlangsung.

c. Analisis Etnomatematika

Analisis etnomatematika dilakukan untuk mengetahui bentuk atau bagian dari candi Joloundo Trawas Mojokerto yang memiliki konsep matematika. Dari hasil analisis ini digunakan untuk merancang dan menentukan materi apa yang dapat digunakan dalam LKS.

2. Design (Desain)

a. Penyusunan Desain LKS

Rancangan penelitian pengembangan LKS matematika berbasis etnomatematika pada materi bangun ruang sisi datar untuk siswa SMP Penanggungan kelas VIII dilakukan dengan langkah-langkah sebagai berikut: 
1) Menentukan Judul LKS

2) Menentukan Desain LKS

b. Penyusunan Desain Instrumen

Penyusunan desain instrumen berfungsi sebagai alat untuk menilai produk atau LKS benar-benar valid. Sebelum instrumen digunakan untuk menilai LKS, desain instrumen divalidasi terlebih dahulu. Setelah desain instrumen dianggap layak sebagai alat uji validitas maka desain tersebut tidak perlu direvisi, begitupun sebaliknya jika desain instrumen belum layak atau perlu direvisi maka desain intrumen tersebut direvisi terlebih dahulu.

3. Development (Pengembangan)

Pada tahap ini, akan dikembangkan LKS matematika berbasis etnomatematika pada materi bangun ruang sisi datar untuk siswa SMP Penanggungan Ngoro Mojokerto kelas VIII yang didasarkan pada hasil validasi ahli dan revisi produk tahap I. Langkahlangkah pengembangan sebagai berikut:

a. Pengembangan LKS:

1) Menentukan Judul LKS

2) Penulisan LKS

b. Pengembangan Instrumen Penelitian

Instrumen penelitian yang digunakan adalah angket validasi ahli materi, angket validasi ahli media, angket validasi ahli bahasa, angket respon siswa, dan angket respon guru. Angket respon guru dan angket respon siswa disesuaikan dari syarat LKS yang baik dengan mengubah struktur bahasanya menjadi bahasa yang komunikatif bagi siswa dan guru, serta didasarkan pada tujuan pengembangan.

c. Validasi Ahli

Validasi ahli merupakan tahapan untuk menentukan kevalidan desain produk yang dikembangkan. Dalam tahap ini peneliti mengharapkan kritik dan saran dari validator.

d. Revisi Tahap I

Tahap ini dilakukan setelah produk dan instrumen selesai divalidasi. Revisi disesuaikan dengan saran dari ahli yang kompeten di bidangnya.

4. Implementation (Penerapan atau Uji Coba)

Pengembangan bahan ajar balok dan kubus berbasis etnomatematika dengan konteks candi Jolotundo Trawas Mojokerto 
Dalam tahap implementation atau penerapan, akan dilakukan uji coba produk. LKS akan diuji cobakan secara terbatas dengan mengambil satu kelas pada kelas VIII di SMP Penanggungan Ngoro Mojokerto.

\section{Evaluation (Evaluasi)}

Evaluasi merupakan proses menganalisis LKS yang dikembangkan. Pada tahap ini jika produk dinilai kurang layak pada saat uji coba maka produk tersebut akan di revisi tahap II. Data-data yang didapat ketika evaluasi akan dijadikan bahan untuk revisi tahap II serta menganalisis apakah produk yang dikembangkan sudah dapat dikatakan valid, praktis dan efektif.

B. Uji Coba Produk

\section{Desain Uji Coba}

Sebelum diujicobakan, produk bahan ajar matematika yang berbentuk LKS divalidasi terlebih dahulu oleh ahli materi, ahli media, dan ahli bahasa kemudian dilakukan revisi tahap I. Produk yang telah direvisi diuji cobakan dalam skala kecil, yakni 6 orang siswa kelas VIII SMP Penanggungan Ngoro Mojokerto secara acak. Produk yang sudah diuji cobakan dievaluasi untuk mengetahui kevalidan produk, dan kemudian dilakukan direvisi tahap II. Produk hasil revisi tahap kedua diujicobakan dalam skala besar, yakni dalam satu kelas yang terdiri dari 29 orang siswa kelas VIII SMP Penangguangan Ngoro Mojokerto.

2. Subjek Uji Coba

Subjek penelitian adalah siswa SMP Penanggungan Ngoro Mojokerto. Objek penelitian dalam penelitian ini adalah kelayakan bahan ajar berupa LKS berbasis etnomatematika pada materi bangun ruang sisi datar kelas VIII. Kelayakan bahan ajar tersebut dilihat dari segi kevalidan, kepraktisan, dan keefektifan.

3. Jenis Data

Data kualitatif disajikan dalam bentuk deskriptif selama proses pengembangan produk, yakni LKS. Data deskriptif berupa saran yang digunakan untuk perbaikan LKS yang dikembangkan. Data kuantitatif ini mendeskripsikan tentang:

a. Kevalidan LKS

Data tersebut diperoleh dari ahli materi, bahasa, dan media.

b. Kepraktisan LKS

Data tersebut diperoleh dari hasil pengisian angket respon siswa dan angket respon guru terhadap penggunaan LKS berbasis etnomatematika dalam proses pembelajaran. 


\section{c. Keefektifan LKS}

Data tersebut diperoleh dari hasil tes yang dilakukan pada siswa SMP Penanggungan Ngoro Mojokerto di kelas VIII materi bangun ruang sisi datar.

Dari data kuantitatif tersebut akan dipergunakan untuk menilai kualitas atau kelayak bahan ajar yang dikembangkan. Menurut Van den Akber Nieveen dalam Rachmad (2010) yang dijelakan oleh tutikmenyatakan bahwa, dalam penelitian pengembangan model pembelajaran perlu kriteria kualitas atau kelayakan yaitu kevaldan (validity), kepraktisan (practically), dan keefektifan (effectiveness). ${ }^{1}$

4. Instrumen Pengumpulan Data

a. Lembar Penilaian Bahan Ajar

Tujuan lembar media ini agar dapat mengetahui kevalidan LKS matematika berbasis etnomatematika, serta kelayakan untuk digunakan di dalam proses pembelajaran. Alternatif jawaban yang digunakan pada angket ini adalah "TST" untuk Sangat Tidak Setuju, "TS" untuk Tidak Setuju, "R" untuk Ragu-ragu, "S" untuk Setuju, "SS" untuk Sangat Setuju. Lembar penilaian diberikan kepada ahli media, ahli bahasa dan ahli materi.

b. Angket Respon Siswa dan Angket Respon Guru

Angket respon siswa dan guru bertujuan untuk mengetahui respon siswa setelah menggunakan LKS dan respon guru terhadap LKS yang digunakan untuk pembelajaran. Alternatif jawaban yang digunakan pada angket ini adalah "TST" untuk Sangat Tidak Setuju, "TS" untuk Tidak Setuju, "KS" untuk Kurang Setuju, "S” untuk Setuju, "SS” untuk Sangat Setuju.

c. Metode Tes

Jenis tes yang digunakan dalam penelitian pengembangan ini berupa post-test. Tes dalam penelitian ini digunakan untuk mengetahui keefektifan penggunaan bahan ajar yaitu LKS berbasis etnomatematika pada materi bangun ruang sisi datar untuk siswa kelas VIII.

\section{Teknik Analisis Data}

Langkah-langkah menganalisis kriteria kualitas produk yang dikembangkan untuk memenuhi aspek kevalidan, kepraktisan dan keefektifan adalah sebagai berikut: a. Analisis Kevalidan

\footnotetext{
${ }^{1}$ Tutik, EprintsUniversitas Yogyakarta, 26.
} 
1) Penyajian data dilakukan oleh validator yaitu dari dosen ahli materi, dosen ahli bahasa dan dosen ahli media. Penyajian data dilakukan dengan memberikan penilaian pada aspek penilaian dengan memberikan tanda ceklis $(\sqrt{ })$.

Tabel 3.1

Pedoman Penskoran Lembar Penilaian Ahli Materi, Ahli Media, dan Ahli Bahasa

\begin{tabular}{|c|c|}
\hline Kategori & Skor \\
\hline Sangat Setuju (SS) & 4 \\
\hline Setuju (S) & 3 \\
\hline Ragu-ragu (R) & 2 \\
\hline Tidak Setuju (TS) & 1 \\
\hline Sangat Tidak Setuju (STS) & 0 \\
\hline
\end{tabular}

Berdasarkan dari data hasil penlilaian ahli materi, ahli bahasa dan ahli media dihitung skor rata-rata dengan rumus:

$$
\bar{x}=\frac{\sum x}{n}
$$

Keterangan:

$\bar{x} \quad=$ rata-rata skor yang dieroleh

$\sum x=$ jumlah skor yang diperoleh

$n \quad$ = banyaknya butir pertanyaan

2) Mengkonversikan skor rata-rata yang diperoleh menjadi nilai kualitatif

Tabel 3.2

Kriteria Penilaian

\begin{tabular}{|c|c|c|}
\hline No. & Rentang Skor Kuantitatif & Kriteria kualitatif \\
\hline 1 & $X>\left(+1,50 S B_{i}\right)$ & Sangat Baik \\
\hline 2 & $\left(+S B_{i}\right)<X \leq\left(+1,50 S B_{i}\right)$ & Baik \\
\hline 3 & $\left(-0,5 S B_{i}\right)<X \leq\left(+S B_{i}\right)$ & Cukup Baik \\
\hline 4 & $\left(-1,50 S B_{i}\right)<X \leq\left(-0,5 S B_{i}\right)$ & Kurang \\
\hline 5 & $X \leq\left(-1,50 S B_{i}\right)$ & Sangat Kurang \\
\hline
\end{tabular}

Sumber: Eko P. Widoyoko

Keterangan:

Skor maksimal ideal $=$ skor tertinggi

Skor minimal ideal $=$ skor terendah

$X=$ Rerata skor ideal $=1 / 2$ skor maksimal ideal + skor minimal ideal

$S B_{i}=$ simpangan baku ideal $=1 / 6($ skor maksimal ideal - skor minimal ideal $)$

$\bar{x}=$ rata-rata skor

3) Menganalisis kevalidan produk LKS 
Kevalidan produk ditentukan dengan menghitung rata-rata nilai aspek untuk tiaptiap validator

Tabel 3.3

Kriteria Validitas Produk Pengembangan

\begin{tabular}{|c|c|}
\hline Interval & Kategori \\
\hline$X>3,4$ & Sangat Baik \\
\hline $2,8<X \leq 3,4$ & Baik \\
\hline $2,2<X \leq 2,8$ & Cukup \\
\hline $1,6<X \leq 2,2$ & Kurang \\
\hline$X \leq 1,6$ & Kurang Baik \\
\hline
\end{tabular}

Sumber: Eko P. Widoyoko

Keterangan:

$X=$ rata-rata skor aktual dari validator

b. Analisis Kepraktisan

1) Angket Respon Siswa

a) Penyajian data diperoleh dari siswa kelas VIII A SMP Penanggungan Ngoro Mojokerto. Siswa mengisi angket dengan memberi tanda $(\sqrt{ })$ dikolom alternatif jawaban yang telah disediakan yaitu SS/Sangat Setuju (skor 4), S/Setuju (skor 3), KS/Kurang Setuju (skor 2), TS/Tidak Sutuju (skor 1), STS/Sangat Tidak Setuju (skor 0).

b) Merubah rata-rata skor menjadi nilai kualitatif menjadi tabel 3.4

c. Analisis Keefektifan Produk LKS

Kefektifan LKS dilihat dari minimal persentase ketuntasan belajar siswa ( $p$ ) yang mengacu pada tabel 6. LKS yang dikembangkan dikatakan efektif apabila minimal persentase ketuntasan belajar siswa termasuk dalam kategori baik.

Ketuntasan belajar individu sesuai dengan KKM yang ditetapkan SMP Penanggungan Ngoro Mojokerto. Ketuntasan belajar siswa pada saat post-test dihitung dengan cara:

$$
p=\frac{\text { banyak siswa yang tuntas }}{\text { banyak siswa dalam satu kelas }} \times 100 \%
$$

Keterangan:

$p=$ persentase ketuntasan belajar

Ketuntasan belajar siswa menggunakan atau mengacu pada tabel berikut:

Tabel 3.5

Pengembangan bahan ajar balok dan kubus berbasis etnomatematika dengan konteks candi Jolotundo Trawas Mojokerto 
Interfal Persentase Ketuntasan Belajar

\begin{tabular}{|c|c|}
\hline Interval & Kategori \\
\hline$p>80$ & Sangat Baik \\
\hline $60<p \leq 80$ & Baik \\
\hline $40<p \leq 60$ & Cukup \\
\hline $20<p \leq 40$ & Kurang \\
\hline$p \leq 20$ & Kurang Baik \\
\hline
\end{tabular}

Sumber: Eko P. Widoyoko

Keterangan:

$p=$ persentase ketuntasan belajar

\section{HASIL DAN PEMBAHASAN}

\section{A. Penyajian Data Uji Coba}

Berdasarkan penelitian dan pengembangan yang dilakukan, diperoleh penyajian data uji coba sebagai berikut:

\section{Hasil Analysis (Analisis)}

Tahap pertama pada penelitian ini adalah Analysis (Analisis). Pada tahap ini peneliti melakukan analisis kebutuhan, karakteristik siswa, dan analisis etnomatematika. Analisis yang dilakukan pada tahap ini adalah sebagai berikut:

a. Hasil Analisis Kebutuhan

Tahap analisis kebutuhan ini bertujuan untuk mengetahui sejauh mana guru mata pelajaran matematika di SMP Penanggungan Ngoro Mojokerto mnggunakan alat peraga dan media pembelajaran dengan baik, serta bagaimana bentuk inovasi media pembelajaran yang dipergunakan. Pada tahap ini peneliti melakukan wawancara pada guru mata pelajaran matematika kelas VIII serta peneliti melakukan observasi pada salah satu kelas VIII. Wawancara dilaksanakan pada tanggal 13 November 2019 dengan narasumber Dra. Tri Endah K.W.

Berdasarkan apa yang ditemukan di lapangan, perlu adanya pengembangan bahan ajar yang dapat memfasilitasi siswa baik untuk penguasaan konsep ataupun tentang pemahaman soal-soal yang dikaitkan dalam kehidupan sehari-hari. Oleh karena itu, peneliti berniat untuk mengembangkan bahan ajar balok dan kubus berbasis etnomatematika dengan konteks candi Jolotundo Trawas Mojokerto.

b. Hasil Analisis Karakteristik Siswa

Berdasarkan observasi yang dilakukan peneliti pada tanggal 13 November 2019, secara umum siswa mengikuti kegiatan belajar mengajar dengan baik. Walaupun 
guru mata pelajaran sudah memfasilitasi siswa dengan diskusi kolompok, siswa tampak jenuh dalam proses belajar mengajar berlangsung. Serta hanya beberapa siswa yang aktif didalam kelompok. Selain itu siswa juga tampak bingung dalam menyelesaikan soal-soal yang diaplikasikan dalam kehidupan sehari-hari.

Berdasarkan hasil analisis tersbut, bahan ajar berbasis etnomatematika pada candi Jolotundo Trawas Mojokerto dapat diterapkan pada siswa SMP Penanggungan Ngoro Mojokerto kelas VIII A, dan dapat diharapkan dapat membantu untuk meningkatkan hasil belajar siswa.

c. Hasil Analisis Etnomatematika

Sebelum peneliti melakukan analisis, peneliti mempunyai keinginan untuk melakukan penelitian pada bangunan candi yang dapat diaplikasikan pada materi bangun ruang sisi datar. Oleh karena itu peneliti melakukan observasi pada tanggal 13 November 2019, secara umum ada berbagai macam aktifitas etnomtematika yang dapat diterapkan pada bangunan candi. Akan tetapi peneliti hanya mengambil beberapa aktifitas saja diantaranya yaitu; aktifitas menjelaskan, aktifitas mengukur, serta aktifitas membuat rancangan bangunan.

Berdasarkan hasil analisis tersebut, candi Jolotundo Trawas Mojokerto sangat cocok untuk diaplikasikan dalam bahan ajar yang peneliti harapkan.

2. Hasil Design (Perancangan)

Tahap kedua dari model pengembangan ADDIE adalah tahap design atau perancangan. Pada tahap ini peneliti mulai melakukan penyusunan desain LKS serta melakukan penyusunan desain instrumen. Untuk penyusunan desain LKS, memiliki dua langkah diantaranya yaitu; menentukan judul LKS, serta menentukan desain LKS.

Berikut adalah hasil penyusunan LKS berbasis etnomatematika dengan konteks candi Jolotundo Trawas Mojokerto:

a. Penyusunan Desain LKS

Rancangan penelitian pengembangan LKS matematika berbasis etnomatematika pada materi balok dan kubus untuk SMP Penanggungan Ngoro Mojokerto kelas VIII dilakukan dengan langkah-langkah sebagai berikut:

1) Menentukan Judul LKS

Berdasarkan analasis kebutuhan, yakni analisis KD, KI, indikator, serta materi.

Judul yang sesuai untuk LKS adalah LKS Berbasis Etnomatematika pada Candi Jolotundo Trawas Mojokerto 
2) Menentukan Desain LKS

Langkah-langkah yang akan dilakukan dalam penulisan LKS sebagai berikut:

a) Perumusan KD

b) Perancangan dari Sisi Media

Perancangan dari sisi media dibagi menjadi 3. Diantaranya yaitu; bagian awal, isi, dan akhir.

1) Bagian Awal
(a) Cover (Sampul)
(b) Daftar Isi
(c) Peta Kompetensi
(d) Sekilas Info

2) Bagian Inti LKS

3) Bagian Akhir LKS

(a) Daftar Pustaka

(b) Glosarium

c) Penyusunan Topik Materi

Setelah peneliti melakukan analisi kebutuhan serta analisis etnomatematika, topik materi yang tepat untuk pengembangan LKS berbasis etnomatematika adalah kubus dan balok.

d) Menentukan Bentuk Evaluasi

Setelah peneliti melakukan analisis karakteristik siswa, siswa yang cenderung bingung ketika menyelesaikan soal cerita yang diaplikasikan dalam kehidupan sehari-hari. Oleh karena itu, peneliti memilih uraian untuk bentuk evaluasi yang terdapat pada LKS berbasis etnomatematika. Peneliti juga memfasilitasi guru dengan kunci jawaban untuk evaluasi yang dikerjakan oleh siswa. Kunci jawaban tersebut bertujuan untuk mempermudah guru ketika mengoreksi hasil evaluasi dari siwa.

b. Penyusunan Desain Instrumen

Penyusunan desain instrumen berfungsi sebagai alat untuk menilai produk atau LKS benar-benar valid. Sebelum instrumen dipergunakan untuk alat validasi produk. Instrumen terlebih dahulu divalidasi agar tidak terjadi masalah saat validasi produk.

Berikut pemaparan masing-masing istrumen penilaian LKS:

1) Uji Kelayakan Ahli Materi 
Lembar uji kelayakan ahli materi sudah disesuaikan dengan standar kurikulum 2013. Dimana gaya belajarnya menggunakan student center, yang artinya kegiatan pembelajaran dipusatkan pada siswa. Pada kasus seperti ini siswa dituntut agar lebih aktif ketika proses belajar mengajar berlangsung. Berikut merupakan rincian aspek penilaian dan banyak butir pernyataan dalam lembar penilaian LKS yang akan diisi oleh dosen ahli materi yang mumpuni.

Tabel 4.1

Rincian Aspek Penilaian dan Banyak Butir Pertanyaan Pada LKS Oleh Dosen Ahli Materi

\begin{tabular}{|l|c|}
\hline \multicolumn{1}{|c|}{ Aspek } & Banyak Butir \\
\hline Materi & 6 \\
\hline Penyajian Materi & 5 \\
\hline Penggunaan Bahasa & 3 \\
\hline \multicolumn{1}{|c|}{ Jumlah } & 14 \\
\hline
\end{tabular}

2) Uji Kelayakan Ahli Media

Lembar uji kelayakan ahli media sudah disesuaikan dengan syarat-syarat yang dibutuhkan untuk menjadi sebuah bahan ajar yang layak pakai. Berikut merupakan rincian aspek penilaian dan banyak butir pernyataan dalam lembar penilaian LKS yang akan diisi oleh dosen ahli media yang mumpuni.

Tabel 4.2

Rincian Aspek Penilaian dan Banyak Butir Pertanyaan Pada LKS Oleh Dosen Ahli Media

\begin{tabular}{|l|c|}
\hline \multicolumn{1}{|c|}{ Aspek } & Banyak Butir \\
\hline Kesesuaian materi LKS dengan KD matematika SMP & 3 \\
\hline $\begin{array}{l}\text { Penyajian LKS runtun serta dapat mengembangkan karakter dan } \\
\text { motivasi siswa }\end{array}$ & 5 \\
\hline $\begin{array}{l}\text { Bahasa yang digunakan sopan, komunikatif, dan sesuai dengan } \\
\text { karakter siswa }\end{array}$ & 5 \\
\hline \multicolumn{1}{|c|}{ Jumlah } & 13 \\
\hline
\end{tabular}

3) Uji Kelayakan Ahli Bahasa

Lembar uji kelayakan ahli bahasa sudah disesuaikan dengan EYD (Ejaan Yang Disempurnakan) yang baik dan benar, serta bahasa yang disesuai diharapkan dapat sesuai dengan sasaran atau siswa. Berikut merupakan rincian 
aspek penilaian dan banyak butir pernyataan dalam lembar penilaian LKS yang akan diisi oleh dosen ahli bahasa yang mumpuni.

Tabel 4.3

Rincian Aspek Penilaian dan Banyak Butir Pertanyaan Pada LKS Oleh Dosen Ahli Bahasa

\begin{tabular}{|c|c|}
\hline Aspek & Banyak Butir \\
\hline $\begin{array}{l}\text { Bahasa yang digunakan baik, benar, lugas, serta mudah } \\
\text { dipahami oleh siswa }\end{array}$ & 2 \\
\hline $\begin{array}{l}\text { Bahasa yang digunakan komunikaf, sesuai dngan } \\
\text { konsep materi }\end{array}$ & 3 \\
\hline Kalimat yang dipakai mewakili isi dan sederhana & 2 \\
\hline $\begin{array}{l}\text { Kesesuaian dngan EYD, konsisten dalam penggunaan } \\
\text { istilah dan simbol }\end{array}$ & 3 \\
\hline Jumlah & 10 \\
\hline
\end{tabular}

4) Angket Respon Siswa

Lembar angket respon siswa sudah disesuaikan dengan kebutuhan dari peneliti, mulai dari isi, kemenarikan, hingga kemudahan ketika menggunakannya. Berikut merupakan rincian aspek penilaian dan banyak butir pernyataan dalam lembar penilaian LKS yang akan diisi oleh para siswa yang sudah menggunakan produk atau LKS tersebut.

Tabel 4.4

Rincian Aspek Penilaian dan Banyak Butir Pertanyaan Pada LKS Oleh Siswa SMP Pennggungan Ngoro Mojokerto

\begin{tabular}{|l|c|}
\hline \multicolumn{1}{|c|}{ Aspek } & Banyak Butir \\
\hline Kemenarikan & 1 \\
\hline $\begin{array}{l}\text { Kejelasan dan kemudahan ketika menggunakan produk } \\
\text { atau LKS }\end{array}$ & 5 \\
\hline Materi yang digunkan mudah dipahami & 7 \\
\hline \multicolumn{1}{|c|}{ Jumlah } & 13 \\
\hline
\end{tabular}

5) Angket Respon Guru

Lembar angket respon guru sudah disesuaikan dengan kebutuhan dari peneliti, mulai dari isi, kemenarikan, hingga kemudahan ketika menggunakannya. Berikut merupakan rincian aspek penilaian dan banyak butir pernyataan dalam lembar penilaian LKS yang akan diisi oleh guru mata pelajaran matematika.

Tabel 4.5

Rincian Aspek Penilaian dan Banyak Butir Pertanyaan Pada LKS Oleh Guru Mata Pelajaran Matematika SMP Penanggungan Ngoro Mojokerto 
3. Hasil

\begin{tabular}{|c|c|}
\hline Aspek & Banyak Butir \\
\hline Tampilan LKS & 7 \\
\hline Bahasa yang dipergunakan LKS & 5 \\
\hline Kejelasan dan kesesuaian & 3 \\
\hline Materi yang disajikan & 3 \\
\hline LKS dapat memfasilitasi dan membantu siswa & 4 \\
\hline Kemudahan dan konsisten dalam penulisan simbol & 4 \\
\hline Jumlah & 26 \\
\hline
\end{tabular}

Development (Pengembangan)

Tahap ketiga dari model pengembangan ADDIE adalah tahap develop atau pengembangan. Tahap ini bertujuan untuk melihat sejauh mana kelayakan LKS yang sudah dirancang. Setelah mendapatkan penilaian kelayakan, LKS direvisi sesuai denga kritik dan saran validator. Validator terdiri dari dosen ahli materi yaitu Dimas Danar Septiadi, M.Pd; dosean ahli media yaitu Masrurotullaily, M.Sc; dan dosen ahli bahasa yaitu Ersy Syafi'i S. Ammah, M.Pd.

a. Hasil Validasi Ahli

1) Penilaian LKS Oleh Dosen Ahli Materi

Berdasarkan hasil penilaian dapat diketahui bahwa kualitas LKS berdasarkan penilaian dosen ahli materi menunjukkan rata-rata 2,7 dari skor rata-rata maksimal 4,0. Dengan demikian LKS dapat dikatakan memiliki kriteria yang cukup baik. Namun demikian tanggapan, kritik, dan saran dari validator ahli materi juga peneliti perhatikan.

2) Penilaian LKS Oleh Dosen Ahli Media

Berdasarkan hasil penilaian dapat diketahui bahwa kualitas LKS berdasarkan penilaian dosen ahli media menunjukkan rata-rata 3,2 dari skor rata-rata maksimal 4,0. Dengan demikian LKS dapat dikatakan memiliki kriteria yang baik. Namun demikian tanggapan, kritik, dan saran dari validator ahli media juga peneliti perhatikan.

3) Penilaian LKS Oleh Dosen Ahli Bahasa

Berdasarkan hasil penilaian dapat diketahui bahwa kualitas LKS berdasarkan penilaian dosen ahli bahasa menunjukkan rata-rata 3,8 dari skor rata-rata maksimal 4,0. Dengan demikian LKS dapat dikatakan memiliki kriteria yang sangat baik. Namun demikian tanggapan, kritik, dan saran dari validator ahli media juga peneliti perhatikan. 


\section{b. Revisi LKS}

Revisi LKS dilakukan berdasarkan tanggapan, kritik, dan saran dari validator. Hal tersebut dilakukan supaya kualitas LKS lebih baik lagi.

\section{Hasil Implementation (Penerapan)}

Tahap keempat dari model pengembangan ADDIE adalah tahap implementation atau penerapan. Setelah dinyatakan layak oleh validator, baik dari valdator ahli materi, ahli media, maupun ahli bahasa. LKS siap untuk diterapkan pada siswa.

Sebelum di uji cobakan secara terbatas, yakni dengan mengambil satu kelas pada kelas VIII peneliti terlebih dahulu menguji cobakan produk pada skala kecil. Dimana uji coba skala kecil terdiri dari 6 siswa yang dipilih secara rendem. Tujuan dari uji coba skala kecil, yaitu untuk mengetahui sejauh mana produk yang dihasilkan sebelum produk tersebut diaplikasikan pada uji skala besar. Pada pelaksanaan uji skala besar ini diikuti oleh 29 siswa dan dilaksanakan dalam 1 kali pertemuan di kelas selama 2 jam pelajaran ( 2 x 45 menit).

Pada tahap ini berjalan sebagaimana peneliti harapkan. Tidak ada kendala yang membuat penelitian terhambat. Proses belajar mengajar juga berjalan sebagaimana mestinya.

\section{Hasil Evaluation (Penilaian)}

Tahap kelima dari model pengembangan ADDIE adalah tahap evaluation atau penilaian. Setelah tahap implementation dilaksanakan, tahap selanjutnya adalah penialain LKS. Pada tahapan ini, penilaian LKS yang dilihat adalah aspek kevalidan, aspek kepraktisan, dan aspek keefektifan dari produk tersebut. Aspek kevalidan dapat dilihat dari pengisian instrumen uji kelayakan. Aspek kepraktisan dapat dilihat dari pengisian instrumen angket respon siswa dan instrumen angket respon guru. Sedangkan aspek keefektifan dilihat dari hasil nilai post-test. Pelaksanaan post-test dan pengisan angket respon siswa dilaksanakan pada tanggal 30 Januari 2020. Berikut pemaparan hasil tahap evaluation adalah sebagai berikut

a. Angket Respon Siswa

Respon siswa terhadap LKS yang telah digunkan menunjukkan kategori yang baik dengan jumlah skor rata-rata skor 3,4 dari jumlah skor rata-rata maksimal 4,0. Berdasarkan hal tersebut LKS tidak perlu direvisi. Sehingga LKS siap untuk diuji cobakan kepada siswa sekala besar. 
Respon siswa terhadap LKS yang telah digunkan menunjukkan kategori yang sangat baik dengan jumlah skor rata-rata skor 3,5 dari jumlah skor rata-rata maksimal 4,0. Berdasarkan hal tersebut LKS tidak perlu direvisi.

b. Angket Respon Guru

Respon guru terhadap LKS yang telah digunkan menunjukkan kategori yang sangat baik dengan jumlah skor rata-rata skor 3,9 dari jumlah skor rata-rata maksimal 4,0. Berdasarkan hal tersebut LKS tidak perlu direvisi.

c. Hasil Post-test

Bedasarkan data yang diambil diperoleh rata-rata 73 dan nilai persentase ketuntasan belajar sebesar 69\%. Berdasarkan hal tersebut pembelajan dengan KLS efektif dan dapat dinyatakan LKS yang dikembangkan baik dari aspek keefektifannya.

B. Analisis Data

1. Analisis Kevalidan LKS

Ananlisis data hasil validasi LKS didasari pada hasil rata-rata validasi 3 dosen ahli, yakni ahli materi, ahli media dan ahli bahasa. Berikut adalah penilaian keseluruhan dari setiap validator:

Tabel 4.21

Data Penilaian Keseluruhan Dari Setiap Validator

\begin{tabular}{|c|l|c|c|}
\hline No. & \multicolumn{1}{|c|}{ Validator } & Rata-rata & Ketegori \\
\hline 1. & Ahli Materi & 2,7 & Cukup Baik \\
\hline 2. & Ahli Media & 3,2 & Baik \\
\hline 3. & Ahli Bahasa & 3,8 & Sangat baik \\
\hline \multicolumn{2}{|c|}{ Rata-rata Keseluruhan } & 3,2 & Baik \\
\hline
\end{tabular}

Berdasarkan data di atas, dapat diketahui bahwa rata-rata keseluruhan adalah 3,2 dengan kategori baik. Dengan demikian LKS dinyatakan valid dan tidak perlu direvisi.

Berdasarkan hasil validasi tersebut, dapat disimpulkan bahwa LKS Berbasis Etnomatematika pada Candi Jolotundo Trawas Mojokerto dinyatakan valid dan tidak memerlukan perombakan yang siginfikan dan layak digunakan sebagai bahan ajar matematika kelas VIII semester genap.

2. Analisis Kepraktisan LKS

Pengembangan bahan ajar balok dan kubus berbasis etnomatematika dengan konteks candi Jolotundo Trawas Mojokerto 
Analisis kepraktisan dengan memberikan angket respon pada saat tahap evaluation. Berdasarkan pada tabel 22 diperoleh nilai kepraktisan dengan rata-rata 3,5 dengan kriteria sangat baik. Sedangkan untuk analisis kepraktisan dengan memberikan angket respon guru, seperti pada tabel 23 diperoleh nilai rata-rata 3,9 dengan kriteria sangat baik. Dari kedua data yang diperoleh, yakni data angket respon siswa dan guru mempunyai rata-rata 3,7 dengan kriteria sangat baik. Sehingga LKS dapat dikategorikan praktis.

Berdasarkan hal tersebut dapat dikatakan bahwa LKS Berbasis Etnomatematika pada Candi Jolotundo Trawas Mojokerto praktis digunakan sebagai salah satu bahan ajar matematika kelas VIII semester genap.

\section{Analisis Keefektifan LKS}

Keefektifan LKS yang dikembangkan dapat dilihat dari presentase ketuntasan belajar siswa. Ketuntasan belajar siswa berasal dari nilai post-test yang dilakukan oleh peneliti pada tahap evaluation. Berdasarkan tabel 24 presentase ketuntasan belajar siswa sebesar 69\%. Dengan demikian, dapat menunjukkan bahwa pembelajaran dengan mengunakan LKS Berbasis Etnomatematika pada Candi Jolotundo Trawas Mojokerto telah memenuhi aspek keefektifan.

Berdasarkan analisis pada hasil post-test dapat disimpulkan bahwa pembelajaran menggunakan LKS Berbasis Etnomatematika pada Candi Jolotundo Trawas Mojokerto efektif digunakan sebagai salah satu bahan ajar matematika kelas VIII semester genap.

Berdasarkan hasil ketiga analisis di atas, dapat disimpulkan bahwa LKS Berbasis Etnomatematika pada Candi Jolotundo Trawas Mojokerto sudah layak digunakan sebagai bahan ajar yang memiliki kualistas valid, praktis, dan efektif.

\section{SIMPULAN DAN SARAN}

Berdasarkan hasil penelitian pengembangan LKS Berbasis Etnomatematika pada Candi Jolotundo Trawas Mojokerto kajian yang dapat diambil sebagai berikut:

1. Proses Pengembangan

Pada proses pengembangan LKS Berbasis Etnomatematika pada Candi Jolotundo Trawas Mojokerto mengacu pada model pengembangan ADDIE, yaitu (1) Analysis (analisis); (2) Design (perancangan); (3) Development (pengembangan); Implementation (penerapan) dan (5) Evaluation (evaluasi). Tahap pertama yang dilakukan ialah tahap Analysis (analisis). Dalam tahap ini terdapat 3 langkah, yaitu 1) Analisis kebutuhan; 2) Analisis karakteristik siswa; dan 3) Analisis Etnomatematika. Tahap ini 
menghasilkan informasi tentang kurikulum, KD dan KI yang digunakan di SMP Penanggungan Ngoro Mojokerto. Selain itu penelti juga mendapatkan informasi bahan ajar apa saja yang digunakan ketika proses belajar mengajar berlangsung. Tidak hanya itu, peneliti juga mendapatkan bagian dari candi Jolotundo yang dapat diaplikasikan kedalam bahan ajar yang akan dikembangkan. Tahap kedua yang dilakukan ialah tahap Design (perancangan). Tahap ini merupakan tahap penyusunan desain LKS, serta penyusunan desain instrumen. Tahap ketiga ialah Development (pengembangan). Dalam tahap ini dilakukan penilaian oleh para ahli yang terdiri dari 3 orang validator. Dari hasil penilaian tersebut diperoleh penilaian kevalidan, kepraktisan, dan keefektifan LKS serta saran dari para validator yang digunakan untuk menghasilkan LKS akhir. Selanjutnya, tahap keempat ialah Implementation (penerapan). Pada tahap ini dilakukan uji coba kepada siswa SMP Penanggungan Ngoro Mojokerto kelas VIII-A dengan diterapkannya pembelajaran menggunakan LKS yang telah dikembangkan. Sedangkan tahap kelima ialah Evaluation (evaluasi). Dalam tahap ini dilakukan penilaian dan analisis terhadap aktivitas siswa, tes hasil belajar dan respon siswa serta guru yang telah diperoleh pada saat penerapan. Pada tahap ini diperoleh hasil penilaian yang digunakan untuk mengetahui keefektifan perangkat pembelajaran.

2. Kelayakan atau Kualitas Bahan Ajar

Bahan ajar yang dikembangkn dapat dikatakan layak untuk dipergunakan. Dikarenakan bahan ajar yang dikmbangkan dapat memenuhi aspek kevalidan, kelayakan, dan kepraktisan seperti yang dijelaskan dibawah ini:

a. Kevalidan

Kriteria valid terpenuhi karena penilaian dari ketiga validator menghasilkan ratarata total dalam kategori baik, dengan nilai rata-rata mencapai 3,2. Dengan demikian LKS yang dikembangkan dapat dinyatakan valid.

b. Kepraktisan

Kriteria praktis terpenuhi karena LKS yang dikembangkan mendapatkan nilai rata-rata 3,9 dengan kriteria sangat baik dari angket respon siswa maupun guru yang sudah disebar. Dari pernyataan tersebut LKS dapat dikatakan praktis untuk digunakan.

c. Keefektifan

Berdasarkan nilai post-test yang diberikan pada tahap uji coba, diperoleh data bahwa sebanyak 69\% siswa dinyatakan tuntas. Dengan demikian LKS dapat dinyatakan efektif ketika dipergunakan. 
- 87

Dari ketiga aspek tersebut dapat diketahui bahwa bahan ajar yang dikembangkan layak untuk dipergunakan.

Berdasarkan hasil penelitian yang diperoleh, maka penulis dapat memberikan saran sebagai berikut:

1. Hendaknya guru dapat mengembangkan perangkat tersebut dengan memanfaatkan lingkungan siswa sebagai sumber belajar, agar siswa dapat mencapai makna dari pengetahuan yang didapat serta dapat mengaplikasikan pengetahuan yang diperolehnya dalam kehidupan sehari-hari.

2. Untuk menguatkan pemahaman siswa terhadap konsep materi, dalam hal ini materi bangun ruang sisi datar, hendaknya ditambahkan latihan-latihan soal pemahaman konsep, serta pengaplikasian dalam kehidupan sehari-hari yang lebih banyak lagi sehingga siswa dapat memahami soal-soal yang berkaitan dengan kehidupan sehari-hari dengan mudah.

\section{DAFTAR PUSTAKA}

\section{Books:}

Arikunto, Suhasimi. (2006). Prosedur Penelitian Suatu Pendekatan Pratik. Jakarta: Rineka Cipta.

Aunurrahman. (2012). Belajar dan Pembelajaran. Bandung: Alfabeta.

Sugiyono. (2017). Metode Penelitian Pendidikan Pendekatan Kuantitatif, Kualitatif, dan $R \& D$. Bandung: Alfabeta.

T, Belawati. (2003). Pengembangan Bahan Ajar. Jakarta: Universitas Terbuka.

Tutik. (2012). Eprints Universitas Negeri Yogyakarta. Yogyakarta: Universitas Yogyakarta. 